\title{
Invaders decrease the structural complexity of the indigenous community of Chozas Lake
}

\author{
S. Bastianoni, M. Marchi \& E. Tiezzi \\ Department of Chemistry, University of Siena, Italy
}

\begin{abstract}
Chozas Lake, a small shallow water body in León, NW Spain, changed from clear water conditions to turbidity in only one year. The cause was loss of abundance and richness of plants due to deliberate introduction and proliferation of the allochthonous Louisiana red swamp crayfish, Procambarus clarkii. The dynamics of this ecosystem have been studied by means of eco-exergy. Eco-exergy is a goal function introduced by S.E. Jørgensen in the 1970s and is related to conformation structures and information in nature with particular attention to evolutionary properties. Its value has been used with that of specific exergy for understanding the quality of biomass variation, seen as a change of the structural complexity of Chozas Lake. The number of crayfish increased as the ecosystem eco-exergy decreased, because the complexity of the ecosystem was higher when there was richness of macrophytes, even if the submerged aquatic vegetation is at lower level on the evolutionary scale than the invasive crustacean. There was a trophic cascade effect on the wetland ecosystem that altered the native community, with loss of invertebrates, amphibia and coots, directly related to plant destruction. However, while fish- and crayfish-eating birds seemed to increase, plant disappearance is a great threat for biodiversity in Spanish lakes because vegetation is the most abundant component of these ecosystems and so its destruction has a very important ecological role.
\end{abstract}

Keywords: crayfish, trophic diversity, eco-exergy, specific eco-exergy, macrophytes, lake.

\section{Introduction}

Procambarus clarkii (Girard, 1852), a decapod crustacean of the family cambaridae, is a native of NE Mexico and central southern USA, specifically 
Louisiana, where nearly 450 million square metres of wetlands are exploited to raise these crayfish for human consumption. The Louisiana red swamp crayfish has now spread to all continents except Australia and Antarctica [1]. It was first imported into Europe (Guadalquivir, southern Spain) in 1974 for aquaculture, and thence into all southern and central European countries [2]. Its high tolerance to changes in abiotic conditions, life-style, rapid population development and ability to acquire food are all evidences of the ecological flexibility of the species, making it an invasive species described as "killer shrimp". It adapts much more readily than indigenous river crayfish (Astacus astacus, Astacus leptodactylus, Astacus pachypus, Austropotamobius torrentium and Austropotamobius pallipes) and therefore tends to replace other species, becoming the strongest link in the ecological chain in the absence of natural predators. This is a bioinvasion: the interaction of invasive and autochthonous species may favour extinction of the latter and contribute to weakening and simplification of food chains, altering prey-predator relations [3].

Mediterranean lakes are characterized by a predominance of plants, the disappearance of which is caused by eutrophication and herbivory. Different species of insects, molluscs, fish and mammals use aquatic vegetation as food, though in these wetlands the disappearance of plants is largely due to herbivorous birds and introduced species such as P. clarkii. An excessive number of birds in lagoons may lead to the gradual disappearance of vegetation due to direct predation and the indirect effects of eutrophication caused by bird excrement. Nevertheless, the introduction and proliferation of $P$. clarkii in Mediterranean freshwater ecosystems have a greater impact than birds [4] because they alter community structure.

The aim of the present study was to determine loss of trophic diversity in Chozas Lake, linked to proliferation of this alien crayfish. When it becomes invasive, populations of this organism increase exponentially and alter habitat food webs as an indirect effect of destruction of the aquatic plant habitat. We have quantitatively compared the complexity and information stored in the Chozas community before the introduction of $P$. clarkii with that during its expansion with the application of an ecological orientor (eco-exergy) and specific exergy index. Jørgensen's eco-exergy in a holistic way describes global design in nature taking into account different disciplines (thermodynamics, ecology and ecological modelling); it can measure how developed an ecosystem is and how far it is from thermodynamic equilibrium.

\section{Materials and methods}

Data on plant biomass samples is reported in Rodríguez et al. [5], where it is observed that most of the submerged vegetation was destroyed at the beginning of summer 1997 due to the expansion of P. clarkii. Biomass went from 800 $\mathrm{gDW} / \mathrm{m}^{3}$ in 1996 to $70 \mathrm{gDW} / \mathrm{m}^{3}$, a decrease of $90 \%$. Changes in chlorophyll $a$ concentrations in $\mu \mathrm{g} / \mathrm{l}$ were obtained from the same source, while photosynthesis of the phytoplankton population was estimated from the concentration of carbon assimilated per hour at light saturation by a gram of phytoplankton chlorophyll $a$ 
[6]. Before 1997, we estimate an absorption of $2.7 \mathrm{~g}$ of carbon per hour for phytoplankton primary production. The slow growth of the phytoplankton population before the invasion showed that it competed with submerged vegetation for nutrients and sunlight, but during expansion of the alien species, the exponential increase of phytoplankton is due to eutrophication from release of organic detritus by vegetation consumed by the crayfish and their excrement. These considerations led us to the hypothesis that carbon absorption in phytoplankton population increased under those particular physicochemical conditions: $10 \mathrm{~g} / \mathrm{h}$ per gram of phytoplankton chlorophyll $a$. During the summer of 1997, Rodríguez et al. [7] monitored the number of P. clarkii on the bed of the lake: one invasive crayfish (mean weight $20 \mathrm{~g}$ ) per square metre. We therefore estimated about 14 specimens of $P$. clarkii $/ \mathrm{m}^{3}$ because we have hypothesized that the concentration of these animals was higher: they were not only on the benthic surface but also in other zones, going up on the leaves of the aquatic vegetation. An estimate of the number of amphibians in the lake before its deterioration was obtained for Hyla arborea (764 specimens of mean weight $4.41 \pm 0.62 \mathrm{~g}$ [8]) from Garcia et al. [9], the only amphibian population study conducted in this area in the past. After the invasion, all Anura species became extremely rare: indeed, it was only possible to find a few adult specimens of Rana perezi and $H$. arborea, which, for simplification, we considered zero. No specimens of Bufo calamita or Pelobates cultripes, common before the invasion, were found. The population of sharp-ribbed salamander (Pleurodeles waltl, mean weight circa $25 \mathrm{~g}$, [10]) maintained a constant number of adult specimens in areas still with vegetation; about 90 specimens were recorded, as in Lake Villaverde, another lake invaded by crayfish and depleted of macrophytes. With regard to water birds, the species most affected by crayfish were coots (Fulica atra, mean body weight about $918 \mathrm{~g}$ [11]) and wild ducks (8 species having a mean weight of $830 \mathrm{~g}$, six of the genus Anas and two of the genus Aythia), which feed mainly on plants and therefore decreased by $65 \%$ and $75 \%$, respectively, after the introduction of this invasive crustacean species. Since the number of water birds present before the crayfish invasion is unknown, we took as reference value the number of specimens of $F$. atra and other migratory ducks on the banks of the Sentiz [12], another lake in the same area, slightly smaller but with the same physicochemical characteristics, oligotrophic and dominated by plants. For macroinvertebrates we used data of García-Criado et al. [13]. We estimated the concentration of biomass $\left(\mathrm{mg} / \mathrm{m}^{3}\right)$ of each genus using a proportion to distribute the total biomass contained in samples from ten different Spanish lakes on the percentage presence of macroinvertebrates in the Chozas samples, before and after the introduction of the alien crayfish. We calculated the concentration of animal biomass in $\mathrm{mg} / \mathrm{m}^{3}$ from the mean weight of representative samples of each species, transforming into dry weight, assuming that about $70 \%$ of the weight of animal organisms is water.

The dry biomass data in $\mathrm{gC} / \mathrm{m}^{3}$ was used to calculate eco-exergy, applied as an indicator of ecosystem health, quantified as the change in the complexity of the community structure in Chozas before introduction and during proliferation of the alien crayfish. To estimate exergy we used the method of Jørgensen [14] 
based on thermodynamic information stored in genomes, that considers the degree of internal organization of organisms. Exergy, a concept derived from classic thermodynamics, is a measure of energy quality and a suitable approach to highlight changes in structural complexity of the community present in the ecosystem. Exergy is assumed to become optimised during ecosystem development, which is supposed to self-organise towards a state of an optimal configuration of this property. In any case, eco-exergy model can provide an interpretation of the natural evolutionary trend of ecosystems and serves as a good indicator of ecological quality. A higher eco-exergy indicates that species have a higher competitive capacity and eventually will have higher probability for survival in the Darwinian sense. Eco-exergy provides information about changes in the structure of ecological niches [15], in the present case, Chozas Lake.

Eco-exergy $(E x)$ for an ecosystem is derived as:

$$
\text { Exergy }=R T \sum_{i}\left[C_{i} \ln \left(\frac{C_{i}}{C_{i}^{e q}}\right)+\left(C_{i}-C_{i}^{e q}\right)\right]
$$

where $R$ is the gas constant, $T$ ambient temperature, $C_{i}$ and $C_{i}^{e q}$ are the concentration of the component $i$ in the ecosystem at the current state and its corresponding concentration at thermodynamic equilibrium, respectively [16]. To facilitate the process, the calculation of eco-exergy index, Ex, can be calculated as:

$$
E x=\sum_{i=1}^{n} \beta_{i} \cdot C_{i}
$$

where $C_{i}$ is the concentration of component $i$ in the ecosystem (for example biomass of a taxonomic or functional group), where $n$ components are present, and $\beta_{i}$ is the weighting factor, which is related to the information stored in the biomass. $\beta_{i} \equiv \ln C_{i} / C_{i}^{e q}$ has been calculated for several organisms and depends on the number of non-nonsense (coding) genes. The $\beta$-values increase with increasing complexity of organisms. Organic detritus is chosen as reference level $(\beta=1)$ and the exergy in biomass of different organisms is expressed in the same unit of detritus equivalent, $\mathrm{kJ} / \mathrm{g}$ [17].

While exergy express the whole information that the biomass is carrying, specific (or structural) exergy is the relative eco-exergy carried (in average) by the unit biomass:

$$
S p E x=E x_{t o t} / \text { Biom }_{\text {tot }}
$$

In addition, specific eco-exergy should be considered a relative index. Since eco-exergy increases with the growth of biomass, specific exergy becomes independent of the biomass or biological structure. Development of the ecological network and growth of the information contained in the ecosystems will imply increase in eco-exergy with or without the change of the biomass for network development but always without the change of the biomass, when the information content in the ecosystem is increasing. Therefore, specific eco- 
exergy will increase often with development of the ecological network and always with increasing information, which is consistent with Prigogine's far from thermodynamic equilibrium thermodynamics. The combination of ecoexergy and the specific eco-exergy usually gives a more effective and comprehensive description of the state of an ecosystem than one index considered alone [18].

\section{Results and discussion}

In the period from 1984 to 1996, Chozas Lake had abundant submerged vegetation and very clear water. After invasion by crayfish, destruction of aquatic vegetation led to higher turbidity due to an increase in organic detritus in the water column. Hypertrophic conditions occurred after the population explosion of $P$. clarkii and were related to the effects of direct predation of submerged macrophytes and deposition of excrement by the invader, whose numbers increased exponentially, covering the whole ecosystem in one year.

Table 1 shows the variation of the concentrations of dry matter $\left(\mathrm{mgC} / \mathrm{m}^{3}\right)$ in the major taxonomic groups present in this aquatic ecosystem before introduction and during proliferation of the invading crayfish, highlighting those classes that were bound to vegetation for their survival. Indeed, aquatic vegetation dominates Spanish lakes and plays a basic ecological role for amphibians, macroinvertebrates and migratory birds by providing food and shelter. Due to the occasional drying-up of lakes, the relative lack of fish and the high concentration of vegetation, the communities of amphibians and macroinvertebrates play a fundamental role in Mediterranean systems, occupying high trophic levels.

The organic carbon content of different genera of macroinvertebrates is shown in Table 2. After introduction of the crayfish in Chozas Lake, $72 \%$ of frequently appearing genera of macroinvertebrates decreased with the disappearance of submerged vegetation. In fact, species of tricoptera and

Table 1: Dry matter content in the major functional groups in Chozas Lake before and after 1997.

\begin{tabular}{|c|c|c|}
\hline \multirow{2}{*}{ Taxonomic groups } & Before 1997 & After 1997 \\
\hline & $\mathrm{mgC} / \mathrm{m}^{3}$ & $\mathrm{mgC} / \mathrm{m}^{3}$ \\
\hline Crayfish (P. clarkii) & 0 & 84,000 \\
\hline Submerged aquatic vegetation & 800,000 & 70,000 \\
\hline Anura $($ H. arborea $)$ & 7 & 0 \\
\hline Urodeles (P. waltl) & 4 & 4 \\
\hline Ducks & 448 & 135 \\
\hline Coots & 661 & 231 \\
\hline Epiphytic macroinvertebrates & 157 & 139 \\
\hline Benthic macroinvertebrates & 141 & 139 \\
\hline Phytoplankton & 44,010 & 685,000 \\
\hline Total & 845,428 & 839,649 \\
\hline
\end{tabular}


Table 2: $\quad$ Dry matter content of epiphytic and benthic macroinvertebrates in Chozas Lake before and after 1997.

\begin{tabular}{|c|c|c|}
\hline \multirow{2}{*}{ Taxonomic groups } & Before 1997 & After 1997 \\
\cline { 2 - 3 } & $\mathbf{m g C} / \mathbf{m}^{\mathbf{3}}$ & $\mathbf{~ m g C / \mathbf { m } ^ { \mathbf { 3 } }}$ \\
\hline Epiphytic macroinvertebrates & & \\
Hydra & 0.4172 & 0 \\
Oligochaeta & 3 & 1 \\
Hirudinea & 0.9734 & 0 \\
Gastropoda & 19 & 0 \\
Acari & 2 & 0 \\
Ostracoda & 1 & 0.4172 \\
Ephemerottera & 8 & 18 \\
Odonata & 77 & 109 \\
Heteroptera & 8 & 0 \\
Lepidottera & 7 & 0 \\
Tricoptera & 4 & 0 \\
Diptera & 27 & 9 \\
\hline Benthic macroinvertebrates & & \\
Oligochaeta & 11 & 24 \\
Diptera & 74 & 115 \\
Others & 56 & 0 \\
\hline Total & $\mathbf{2 9 8}$ & $\mathbf{2 7 8}$ \\
\hline
\end{tabular}

heteroptera disappeared completely, along with whole classes of gastropods, lepidoptera, hydra, acari and hirudinea. On the other hand, certain species of epiphytic odonates and benthic dipterans and oligochaetes increased in biomass, suggesting that they were not part of crayfish's diet or crayfish had trouble catching them.

Tables 1 and 2 indicate biomass distribution of organic carbon among the different plant and animal classes in the lake before and after 1997. It is evident that before introduction of the alien crayfish, most biomass was concentrated in aquatic macrophytes, whereas after 1997 phytoplankton achieved high density, followed by the invader itself, with plants in third place: a decrease in biomass of at least $90 \%$ with respect to the previous year. This was absolutely striking since plant cover did not change significantly in Chozas Lake in the 12-year period 1984-1996. The other classes of species showed much lower biomass concentrations, almost insignificant with respect to vegetation, phytoplankton and the alien crayfish at the peak of the invasion.

Figure 1 shows that $P$. clarkii voraciously consumed plant matter. Other studies [19] have also shown a preference of the crayfish for plants. Nevertheless, other studies have shown that organic detritus is often found in crayfish stomachs, being a nourishing food by virtue of the large quantity of bacteria it contains (see e.g. [20]). This is why P. clarkii seems able to subsist 

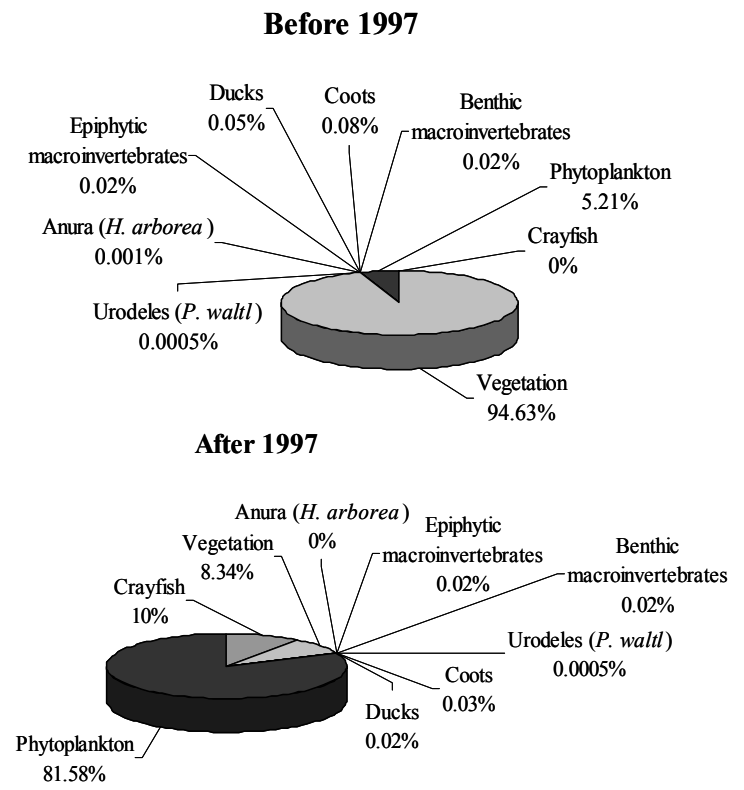

Figure 1: Percentage distribution of organic carbon stored in different taxonomic groups before the introduction and after the expansion of $P$. clarkii.

even on a diet consisting largely of decomposed matter, depending on the nutritional value of the microbe fraction of detritus; indeed, according to Ilhéu and Bernardo [21] this species plays a more important role in ecosystems as decomposer than as herbivore.

As shown in Figure 1, the concentration of crayfish biomass increased exponentially with decreasing vegetation until it reached $10 \%$ of the total biomass, despite the fact that aquatic vegetation was only $8.34 \%$. This is a clear sign that the invader, a general and opportunistic feeder, succeeds in adapting to changes in habitat, feeding on any available resource: in this case it fell mainly on macrophytes, macroinvertebrates, eggs and larvae of amphibia in the first phase of invasion and on organic detritus in all stages, especially when the other resources were depleted.

The progressive disappearance of vegetation caused by invaders led to a loss of complexity of the lake community. The increase in organic detritus and hence the increase in nutrient concentrations in the water column led to turbidity caused by the massive proliferation of phytoplankton and resuspension of sediment by wind in the absence of vegetation [22]. Under such unbalanced conditions, zooplankton could not control phytoplankton blooms. The absence of shelter provided by vegetation makes planktonic microcrustaceans more vulnerable to predation by fish, favouring an increase in the phytoplankton population and a cascade of mechanisms reinforcing turbidity. 
Before the invasion of $P$. clarkii, there were four species of fish in Chozas Lake: Tinca tinca, Carassius auratus, Chondrostoma arcassi and Gambusia affinis, [7]. Although fishes and certain families of birds, such as Ardeidae, Ciconidae and cormorants, increased in number after the crayfish population explosion, Rodríguez et al. [5; 7] found a sharp decrease in total biodiversity of this ecosystem.

Although the eco-exergy of an ecosystem cannot be calculated exactly, since it is impossible to measure concentrations of all components and accurately quantify all contributions to exergy, we were nevertheless able to estimate the biomass content of the organisms that played a fundamental role in the food web of the lake before and after the invasion.

Figure 2 shows that the decrease in global biomass, characterizing the period after introduction of the crayfish, led to an overall decrease in eco-exergy of the ecosystem. The loss of biomass determined a decrease of the development of the ecological network.

At the same time, the specific exergy passed from 89 to $48 \mathrm{~kJ} / \mathrm{g}$ before and after the proliferation of the invasive crayfish, respectively. Although aquatic vegetation occupies a lower position than crustaceans in the evolutionary scale (as shown by the respective $\beta$-values [14]), the health status of the ecosystem in question was favoured by its abundance, determining decreasing well-being with increasing invasion. It means that specific exergy express whether the ecosystem is populated by more or less advanced organisms. The specific exergy, in fact, confirm the importance played by the vegetation that has stored a higher degree of internal information than phytoplankton, which was the most dominant component in the habitat after invasion. Indeed, specific exergy value is decreased when the concentration of phytoplankton grows, after the disappearance of the macrophytes. Due to the decrease of the biomass quality, the expansion of $P$. clarkii in Chozas Lake created an ecosystem characterized by greater internal vulnerability and therefore an overall increase in entropy, since the decrease in density of certain species led to loss of information. The alien crayfish had a direct negative effect on the ecosystem by elimination of submerged vegetation and reduction of macroinvertebrate populations; both effects led to a massive decrease in food resources, influencing the food web. Even if the density of crayfish declined, the loss of vegetation had led to a state of turbidity that had negative effects on light conditions, making subsequent recolonization by aquatic macrophytes difficult.

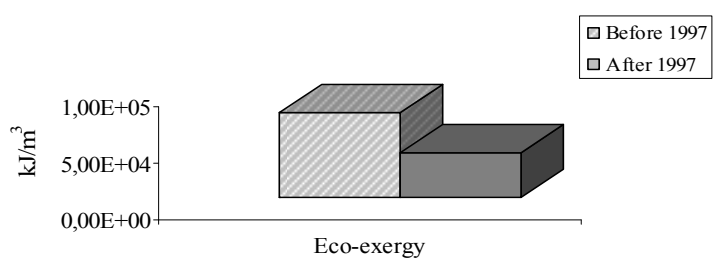

Figure 2: Eco-exergy of the community of Chozas Lake before and after 1997. 


\section{Conclusion}

The results of eco-exergy analysis can approximate the increase of entropy in Chozas Lake after the introduction of the alien crayfish. The link between this index with specific exergy quantifies the degree of development of the ecological network of the lake, describing how this self-organized ecological system developed by keeping its state as far as possible from thermodynamic equilibrium [23]. The drop of eco-exergy and the increase of eutrophication indicated the evolutionary decrease of the ecosystem, since after invasion less complex organisms were dominant: primary production was mainly due to phytoplankton and not submerged macrophytes. At the beginning of the invasion $P$. clarkii had a high competitive capacity determining, subsequently, a difficult condition of survival for itself and other species, due to the alteration of the natural equilibrium of the lake.

\section{References}

[1] Hobbs III, H.H., Jass, J.P. \& Huner, J.V., A review of global crayfish introductions with particular emphasis on two north American species (Decapoda, Cambaridae). Crustaceana, 56, pp. 299-316, 1989.

[2] Gherardi, F. \& Holdich, D.M. (Eds.), Crayfish in Europe as alien species. Crustacean Issues 11. A.A. Balkema, Rotterdam, The Netherlands, 1999.

[3] Petrella, S., Problematiche di conservazione della biologia: l'impatto delle specie alloctone. In: Petrini, R. \& Venturato, E. (Eds.), La gestione delle specie alloctone in Italia: il caso della nutria e del gambero rosso della Louisiana. Quaderni del Padule di Fucecchio n. 2., 2002.

[4] Bécares, E., Conty, A., Rodríguez-Villafañe, C. \& Blanco, S., Funcionamento de los lagos someros mediterráneos. Ecosistemas, 13(2), pp. 2-12, 2004.

[5] Rodríguez, C.F., Bécares, E., Fernández-Aláez, M. \& Fernández-Aláez, C., Loss of diversity and degradation of wetlands as a result of introducing exotic crayfish. Biological Invasions, 7, pp. 75-85, 2005.

[6] Ryther, J.H. \& Yentsch, C.S., The Estimation of Phytoplankton Production in the Ocean from Chlorophyll and Light Data. Limnology and Oceanography, 2(3), pp. 281-286, 1957.

[7] Rodríguez, C.F., Bécares, E. \& Fernández-Aláez, M., Shift from clear to turbid phase in Lake Chozas (NW Spain) due to the introduction of American red swamp crayfish (Procambarus clarkii). Hydrobiologia, 506(509), pp. 421-426, 2003.

[8] Márquez, R., Moreira, C., Da Amaral, J.P.S., Pargana, J.M. \& Crespo, E.G., Sound pressure level of advertisement calls of Hyla meridionalis and Hyla arborea. Amphibia-Reptilia, 26, pp. 391-395, 2005.

[9] Garcia, C., Salvador, A. \& Santos, F.J., Ecología reproductiva en una charca temporal de León (Anura: Hylidae). Revista Española de Herpetología, 2, pp. 33-47, 1987. 
[10] Díaz-Paniagua, C., Gómez-Rodríguez, C., Portheault, A. \& De Vries, W., Los anfibios de Doñana. Naturaleza y parques nacionales. Serie técnica. Organismo Autónomo Parques Nacionales, Madrid. pp 181, 2005.

[11] Ponton, F., Montes, L., Castanet, J. \& Cubo, J., Bone histological correlates of high-frequency flapping flight and body mass in the furculae of birds: a phylogenetic approach. Biological Journal of the Linnean Society, 91, pp. 729-738, 2006.

[12] Rodríguez-Villafañe, C., Bécares, E. \& Fernández-Aláez, M., Waterfowl grazing effects on submerged macrophytes in a shallow mediterranean lake. Aquatic Botany, 86, pp. 25-29, 2007.

[13] García-Criado, F., Bécares, E., Fernández-Aláez, C. \& Fernández-Aláez, M., Plant-associated invertebrates and ecological quality in some Mediterranean shallow lakes: implications for the application of the EC Water Framework Directive. Aquatic Conservation: Marine and Freshwater Ecosystems, 15, pp. 31-50, 2005.

[14] Jørgensen, S.E., Exergy. In: Jørgensen, S.E. \& Fath, B.D. (Eds.), Encyclopedia of Ecology, Elsevier, Oxford, pp. 1498-1509, 2008.

[15] Jørgensen, S.E., Overview of the model types available for development of ecological models. Ecological Modelling, 215, pp. 3-9, 2008.

[16] Zhang, J., Gurkan, Z. \& Jørgensen, S.E., Application of eco-exergy for assessment of ecosystem health and development of structurally dynamic models. Ecological Modelling, 221, pp. 693-702, 2010.

[17] Jørgensen, S.E, Ladegaard, N., Debeljak, M. \& Marques, J.C., Calculations of exergy for organisms. Ecological Modelling, 185, pp. 165-175, 2005.

[18] Jørgensen, S.E, Specific Exergy as Ecosystem Health Indicator. In: Jørgensen, S.E. \& Fath, B.D. (Eds.), Encyclopedia of Ecology, Elsevier, Oxford, pp. 3332-3333, 2008.

[19] Gutiérrez-Yurrita, P.J., Sancho, G., Bravo, M.Á., Baltanás, Á. \& Montes, C., Diet of the red swamp crayfish Procambarus clarkii in natural ecosystems in the Doñana national park temporary fresh-water marsh (Spain). Journal of Crustacean Biology, 18(1), pp. 120-127, 1998.

[20] Brawn, P.B., Review of crayfish nutrition. Crustacean Nutrition Newsletters, 6, pp. 68-69, 1990.

[21] Ilhéu, M. \& Bernardo, J.M., Aspects of trophic ecology of red swamp crayfish (Procambarus clarkii, Girard) in Alentejo, south of Portugal. In: Actas VI Congreso Español de limnologia, pp. 417-427, Granada, 1993a.

[22] Weisner, S.E.B., Strand, A. \& Sandsten, H., Mechanisms regulating abundance of submerged vegetation in shallow eutrophic lakes. Oecologia, 109, 592-599, 1997.

[23] Jørgensen, S.E., Fath, B.D., Bastianoni, S., Marques, J.C., Müller, F., Nielsen, S.N., Patten, B.C., Tiezzi, E. \& Ulanowicz, R.E., A New Ecology: Systems Perspective, Elsevier, Amsterdam, pp. 288, 2007. 